Artikel Riset

Pemetaan Lahan Sub-Optimal Berbasis Nilai NDVI Sentinel 2a: Studi Pendahuluan

\title{
Mapping of Sub-Optimal Land Based on NDVI Sentinel 2a Value: A Preliminary Study
}

\author{
Indarto $^{1^{*}}$, Rufiani Nadzirah ${ }^{1}$, Hadrian Reksa Belagama ${ }^{1}$ \\ ${ }^{1}$ Program Studi Teknik Pertanian, Universitas Jember, Jl. Kalimantan No. 37 Jember, Indonesia 68121 \\ * Penulis korespondensi, e-mail: indarto.ftp@unej.ac.id
}

\begin{abstract}
Abstrak
Normalized Difference Vegetation Index (NDVI) merupakan salah satu indeks vegetasi yang digunakan untuk menganalisis kerapatan vegetasi. Penelitian ini menyajikan potensi aplikasi NDVI untuk memetakan Lahan Sub-Optimal kering (LSO-kering). Penelitian dilakukan di bagian timur wilayah Kabupaten Situbondo yang mencakup tiga kecamatan, yaitu, Arjasa, Asembagus dan Jangkar. Citra Sentinel 2A rekaman tahun 2018 yang sudah terkoreksi dan 450 training area atau GCP (Ground Control Point) digunakan sebagai input utama. Wilayah tersebut merupakan daerah dengan karakteristik iklim yang khas, dimana musim kemarau lebih lama dibanding dengan musim penghujan. Analisis menggunakan tool "plug-in SNAP" dan "QGIS". Prosedur penelitian mencakup: (1) inventarisasi data, (2) pra-processing data, (3) processing data dan (4) uji akurasi. Klasifikasi NDVI dapat membedakan 6 kelas peruntukan yaitu : badan air, area pemukiman, LSO-kering, tegalan-sawah tadah hujan, sawah irigasi, hutan-perkebunan. Klasifikasi NDVI menghasilkan nilai Overall dan Kappa akurasi sebesar $66,9 \%$ dan 61,6\%. Nilai akurasi yang didapat masih jauh dari standar klasifikasi, namun metode ini dapat menjadi pijakan penelitian selanjutnya terkait dengan indek citra yang dapat digunakan untuk identifikasi LSO-Kering.
\end{abstract}

Kata kunci: Sentinel 2A; NDVI; Klasifikasi; lahan-pertanian; sub-optimal; kering

\begin{abstract}
Normalised Difference Vegetation Index (NDVI) is one of the vegetation indices used to analyse vegetation density. This study presents the potential use of NDVI to map dry-marginal-agricultural land (Dry-MAL). The study conducted in the eastern part of Situbondo, which includes three districts, namely, Arjasa, Asembagus and Jangkar. Sentinel-2A (recorded in 2018) and 450 Control points (GCPs) are used as the primary input. The region is an area with distinctive climate characteristics, where the dry season is longer than the rainy season. Analysis using "SNAP plug-ins" and "QGIS". Research procedures include (1) data inventory, (2) data pre-processing, (3) data processing and (4) accuracy testing. The NDVI classification can distinguish six (6) classes of land-use, i.e., water bodies, residential areas, dry MAL, non-irrigated rural area, irrigated paddy fields, forest-plantations. The NDVI classification produces Overall and Kappa accuracy values $=66,9 \%$ and $61,6 \%$. Although the overall and kappa accuracy is below the standard, however, the result will benefit for further research of index vegetation or soil more applied for the identification of Dry-MAL.

Keywords: sentinel 2A; NDVI; classification; dry-marginal; agricultural-land;
\end{abstract}




\section{Pendahuluan}

Secara geografis, wilayah Kabupaten Situbondo berada pada posisi $113^{\circ} 30^{\prime}-114^{\circ} 42^{\prime}$ Bujur Timur dan $7^{\circ} 35^{\prime}-7^{\circ} 44^{\prime}$ Lintang Selatan. Kabupaten Situbondo memiliki iklim tropis, dengan suhu rata-rata mencapai $25,8^{\circ} \mathrm{C}-30^{\circ} \mathrm{C}$. Kabupaten Situbondo pada umumnya memiliki rata-rata curah hujan antara 115,66 mm perbulan dan tergolong kering (BPS, 2016). Lahan sub-optimal merupakan lahan yang telah mengalami degradasi yang mempunyai kesuburan yang rendah dan tidak mampu mendukung pertumbuhan tanaman secara optimal (Ballitanah, 2016; Naser dkk., 2020). Lahan sub-optimal secara alamiah mempunyai produktivitas rendah yang disebabkan oleh faktor internal (intrinsik) seperti bahan induk, sifat fisik, kimia dan biologi tanah dan faktor eksternal seperti curah hujan dan suhu ekstrim (Gherardi \& Sala, 2019; Las, I. \& Mulyani, 2012; Zewdie dkk., 2017). Akibat dari rata-rata curah hujan yang tergolong kering, Kabupaten Situbondo memiliki banyak lahan sub-optimal seperti tanah tandus, tanah rusak, dan semak belukar terutama pada wilayah Kecamatan Arjasa, Asembagus dan Jangkar. Wilayah 3 kecamatan tersebut merupakan suatu daerah dengan karakteristik iklim yang khas, dimana musim kemarau lebih lama dibanding dengan musim penghujan. Wilayah lahan sub-optimal memiliki potensi pemanfaatan lebih lanjut seperti cadangan lahan pertanian dan kehutanan (Blankenship dkk, 2019). Identifikasi lahan sub-optimal tersebut digunakan sebagai langkah awal dalam upaya peningkatan produktivitas lahan sub-optimal (Ghazanfari dkk., 2013; Glenn dkk., 2016). Lahan sub-optimal pada daerah kering memiliki intensitas vegetasi yang minim (Bayramov dkk., 2016) pada musim kemarau hal tersebut digunakan sebagai acuan dalam ide penelitian ini. Indeks vegetasi merupakan metode transformasi citra berbasis data spektral yang dimanfaatkan untuk pengamatan analisis vegetasi (Rahaman dkk., 2017). Pengamatan analisis vegetasi dapat menggunakan berbagai macam metode, salah satunya adalah metode NDVI atau Normalised Difference Vegetation Index (Gu dkk., 2008). Metode NDVI memanfaatkan fenomena fisik pantulan gelombang cahaya yang berasal dari dedaunan sehingga memudahkan dalam mendeteksi adanya suatu vegetasi (Danoedoro, 2012).

Salah satu citra satelit yang dapat digunakan untuk mendapatkan informasi indeks vegetasi adalah citra satelit sentinel-2A (Osgouei dkk., 2019). Satelit sentinel-2A merupakan salah satu data citra satelit yang dapat diperoleh dengan tanpa biaya, mudah diakses dan memiliki resolusi yang cukup baik (Bontemps dkk., 2015). Tinjauan teoritis dan pustaka tentang pemanfaatan metode klasifikasi NDVI dengan data sentinel telah banyak dilakukan oleh peneliti. Misalnya, analisis kesehatan hutan mangrove berdasarkan metode klasifikasi NDVI pada Citra Sentinel-2 (Kawamuna dkk., 2017). Analisis ketersediaan ruang terbuka hijau dengan Metode NDVI dan SAVI (Soil Adjusted Vegetation Index) menggunakan Citra Satelit Sentinel-2a (Sinaga dkk., 2018).

Gu dkk., (2008) mengevaluasi hubungan antara NDVI dan Normalised Difference Water Index (NDWI) dengan kelembaban tanah. Nilai NDVI dan NDWI diperoleh dari satelit Moderate Resolution Imaging Spectro-radiometer (MODIS). Pengamatan dilakukan pada tahun 2002 - 2006. Hasil dari penelitian ini menunjukkan bahwa korelasi antara NDVI dan NDWI dengan Fractional Water Index (FWI) sangat tergantung pada heteroginitas jenis tutupan lahan dan jenis tanah. Korelasi tertinggi antara kedua Index dengan FWI terdapat pada area dengan karakter tutupan lahan yang relatif homogen dengan tekstur tanah silt loam $(\mathrm{r} \sim 0,73)$, sedangkan area dengan tutupan lahan bervegetasi heterogen dan bertekstur loam memiliki korelasi terendah $(\mathrm{r} \sim 0,22)$. Selanjutnya, Chen dkk. (2014) melakukan penelitian serupa tentang pengukuran dampak kelembapan tanah terdadap NDVI, lokasi penelitian adalah seluruh daratan Australia antara tahun 1991 hingga 2009. Metode yang digunakan untuk mengukur korelasi antara kelembaban tanah dan NDVI adalah windowed cross correlation; quantile regression; piecewise linear-regression. Penelitian ini menunjukkan hubungan yang signifikan $(\mathrm{p}<\mathrm{o}, 1)$ antara kelembapan tanah dengan NDVI dengan pola respon NDVI tertinggal 1 bulan terhadap kelebaban tanah.

Ahmed dkk. (2017) melakukan penelitian serupa di Sahel, Afrika dimana karakteristik dari area ini adalah kering. Terdapat dua periode jenis data yang digunakan, pertama recovery rainfall period $(1982$ - 1997) dan stable rainfall period (1998 - 2013). Hasil korelasi dari penelitian ini menunjukkan 
bahwa terdapat hubungan yang positif signifikan antara NDVI dan kelembaban tanah dimana lag respon vegetasi tertinggal satu bulan terhadap kelembaban tanah. Pendekatan tersebut nantinya akan berguna untuk mengidentifikasi trend spasial antara kelembaban tanah dan NDVI dan dapat digunakan sebagai modelling untuk memetakan perubahan vegetasi dan ekosistem.

Penelitian ini bertujuan untuk identifikasi dan memetakan lahan sub-optimal kering (LSOkering) dengan memanfaatkan nilai $N D V I$ yang diturunkan dari citra Sentinel-2A sebagai kriteria klasifikasi. Harapannya adalah dihasilkan suatu peta tematik LSO-kering terklasifikasi.

\section{Metode Penelitian}

Penelitian ini dilaksanakan mulai bulan Maret-Oktober 2019. dan wilayah penelitian ini yaitu di Kabupaten Situbondo (Arjasa, Asembagus dan Jangkar). Pengolahan data dilaksanakan di Laboratorium Teknik Pengendalian dan Konservasi Lingkungan (lab TPKL), Fakultas Teknologi Pertanian, Universitas Jember.

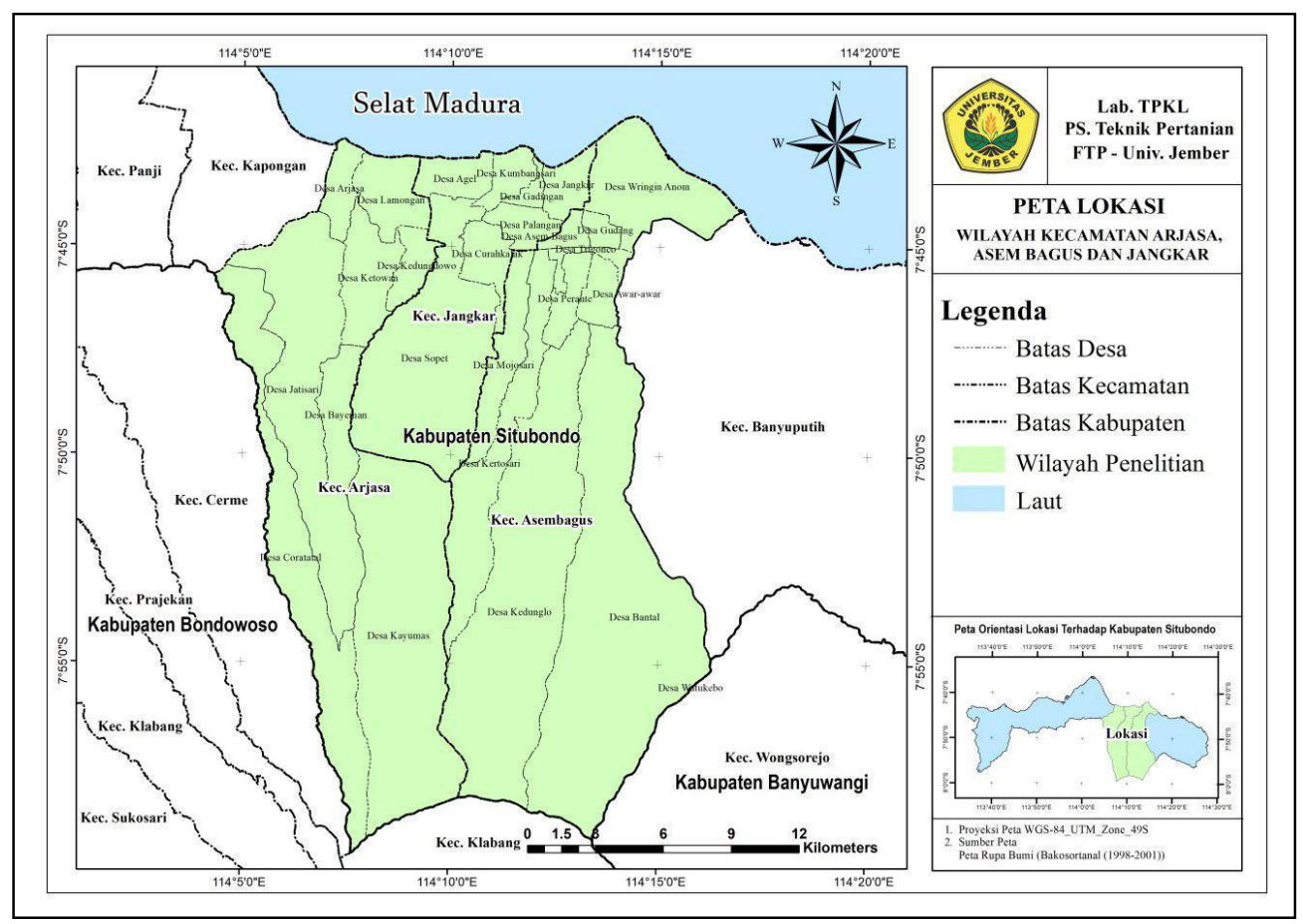

Gambar 1. Lokasi penelitian

Alat yang digunakan pada penelitian ini yaitu seperangkat PC (Personal Computer) digunakan untuk mengolah data dan menganalisis data. Plug-in SNAP "sen2core" digunakan untuk koreksi atmosferik data citra sentinel-2A. Q-GIS 3.2.o digunakan untuk cliping citra dan transformasi NDVI. Arc-GIS 10.3 digunakan untuk mencari reclassify dan membuat layout. Microsoft Excel digunakan untuk merekap data dan mencari rentang nilai NDVI. Kemudian GPS untuk mengambil titik sampel dan Google earth image untuk melihat kecocokan keadaan yang ada dilapang.

Bahan yang digunakan pada penelitian ini yaitu data citra satelit sentinel waktu perekaman tahun 2018 yang diperoleh dari laman USGS (https://earthexplorer.usgs.gov/) (USGS, 2019). Citra sentinel memiliki 13 band dengan format jpeg dan metadata berformat txt. Data sentinel yang diambil adalah data dengan presentase tutupan awan kurang dari 10\% (Tabel 1). Tabel (1) menampilkan citra sentinel yang mewakili musim kemarau, yaitu bulan Mei, Juni, Juli, Agustus, September dan Oktober. Periode musim kemarau dipilih agar dapat membedakan nilai dari LSO-kering menggunakan nilai turunan dari NDVI. 
Tabel 1. Sumber data citra Sentinel-2

\begin{tabular}{|c|c|c|c|c|}
\hline No & $\begin{array}{c}\text { Date } \\
\text { accuired }\end{array}$ & $\begin{array}{c}\text { Cloud cover } \\
(\%)\end{array}$ & Orbit & Data type \\
\hline 1 & $01 / 05 / 2018$ & 1,65 & Descending & $\mathrm{S}_{2} \mathrm{MSI}_{1} \mathrm{C}$ \\
\hline 2 & 15/o6/2018 & 3,47 & Descending & $\mathrm{S}_{2} \mathrm{MSI}_{1} \mathrm{C}$ \\
\hline 3 & 20/07/2018 & 0,68 & Descending & $\mathrm{S}_{2} \mathrm{MSI}_{1} \mathrm{C}$ \\
\hline 4 & $24 / 08 / 2018$ & 22,13 & Descending & $\mathrm{S}_{2} \mathrm{MSI}_{1} \mathrm{C}$ \\
\hline 5 & $18 / 09 / 2018$ & 3,7 & Descending & $\mathrm{S}_{2} \mathrm{MSI}_{1} \mathrm{C}$ \\
\hline 6 & $08 / 10 / 2018$ & 1,05 & Descending & $\mathrm{S}_{2} \mathrm{MSI}_{1} \mathrm{C}$ \\
\hline
\end{tabular}

Data training area diperoleh selama kegiatan survey lapang dari Juni sd Oktober 2019. Data training area juga diambil dari Google Earth Image. Selanjutnya, batas wilayah kabupaten dan kecamatan diunduh dari portal Badan Informasi Geospatial atau biasa disingkat BIG (http://tanahair.indonesia.go.id/portal-web).

Pengolahan data dibagi menjadi 3 tahap yaitu pre-processing, processing dan uji akurasi. Preprocessing terdiri dari koreksi atmosferik dan clipping citra. Koreksi atmosferik adalah bagian dari pra pengolahan data citra yang digunakan untuk menghilangkan kesalahan radiasi yang terekam pada citra sebagai akibat dari hamburan atmosfer (path radiance). Proses koreksi atmosferik dilakukan dengan menggunakan plugin "senzcore" dari ESA-SNAP 6.o. Clipping citra sesuai dengan wilayah penelitian yang mencakup 3 Kecamatan (Arjasa, Asembagus dan Jangkar) dilakukan menggunakan software Q-GIS 3.2.o. Tahap processing mencakup tranformasi, identifikasi, analisis statistik dan klasifikasi nilai NDVI. Tranformasi NDVI dilakukan untuk mengetahui sebaran vegetasi. Transformasi NDVI dilakukan menggunakan software Q-GIS 3.2.o. dengan algoritma (Putra, Soni, Marhaenanto, Harsono, \& Fountas, 2019):

$$
\text { NDVI }=\frac{\text { NIR }- \text { Red }}{\text { NIR }+ \text { Red }}
$$

Keterangan $:$ NIR $=$ Band 8 dan RED $=$ Band 4.

Transformasi NDVI dilakukan untuk citra sentinel bulan Mei, Juni, Juli, Agustus, September dan Oktober. Identifikasi nilai NDVI dilakukan untuk mencatat nilai NDVI pada 450 titik GCP (Gambar 2).

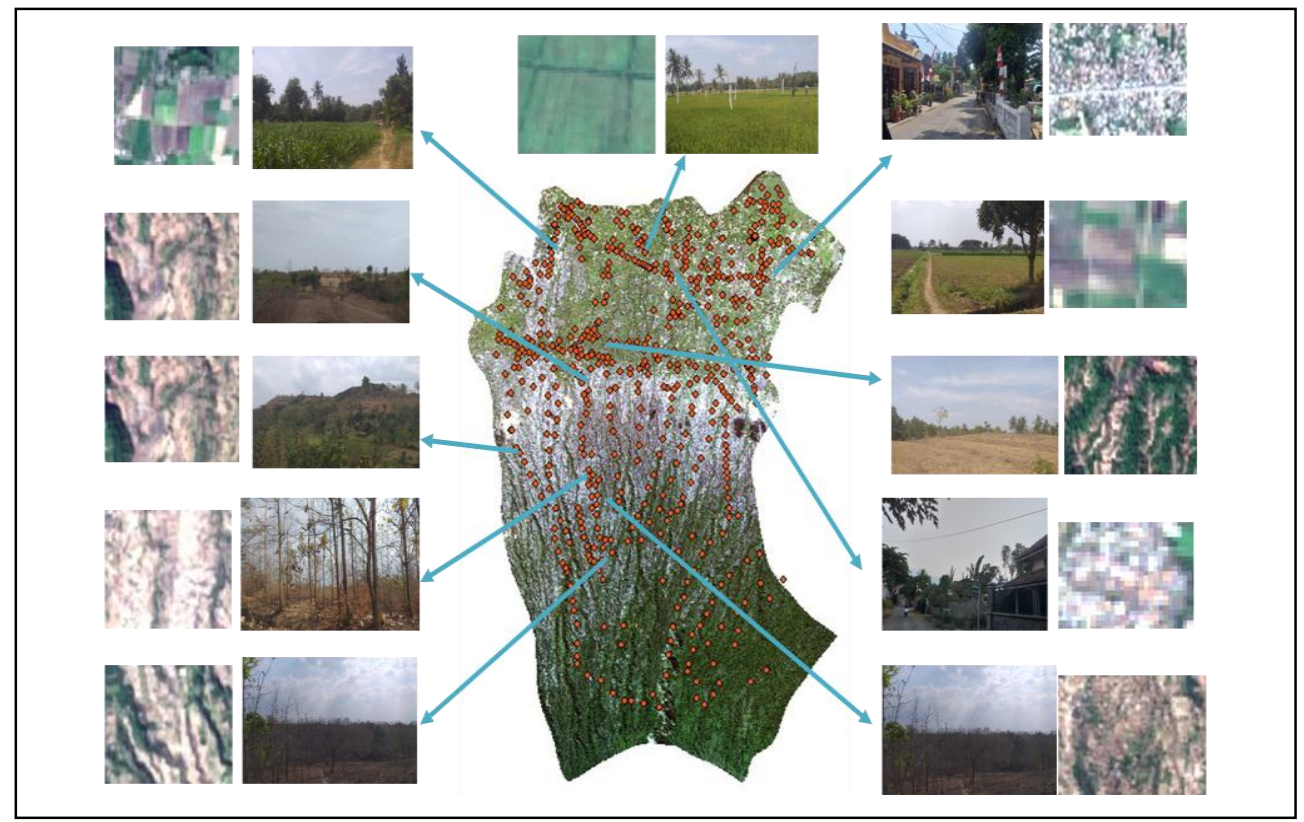

Gambar 2. Lokasi 450 GCP yang digunakan 
Analisis statistik dilakukan dengan Excel. Nilai NDVI yang sudah diidentifikasi, selanjutnya ditabulasi dengan excel. Kemudian dilakukan analisis statistik untuk mencari nilai modus-max dan modus min pada setiap kelasnya untuk mengetahui rentang nilai NDVI. Setelah rentang nilai NDVI diketahui, selanjutnya dihitung nilai rerata (overlay) NDVI dari bulan Mei sampai dengan Oktober. Setelah itu pada tahap processing, dilakukan klasifikasi NDVI. Klasifikasi menggunakan rentang nilai NDVI yang telah diketahui pada layer yang telah di overlay. Penilaian akurasi menggunakan table confussion matrix overall dan kappa (kappa accuracy), sebagaimana layaknya perhitungan analisis data citra (Clerici dkk., 2017; Jaya \& Surati, 2010).

\section{Hasil dan Pembahasan}

3.1 Transformasi NDVI

Gambar (3) menampilkan hasil analisis NDVI untuk bulan Mei (a), Juni (b), Juli (c), Agustus (d), September (e), dan Oktober (f). Warna hijau tua menunjukkan nilai indeks vegetasi (NDVI) yang semakin tinggi. Semakin pudar warna hijau-nya maka semakin rendah nilai NDVI. Sebaran niai NDVI bulan Mei hingga Juli terlihat identik. Sebaran Nilai NDVI Agustus, September, Oktober juga terlihat identik.

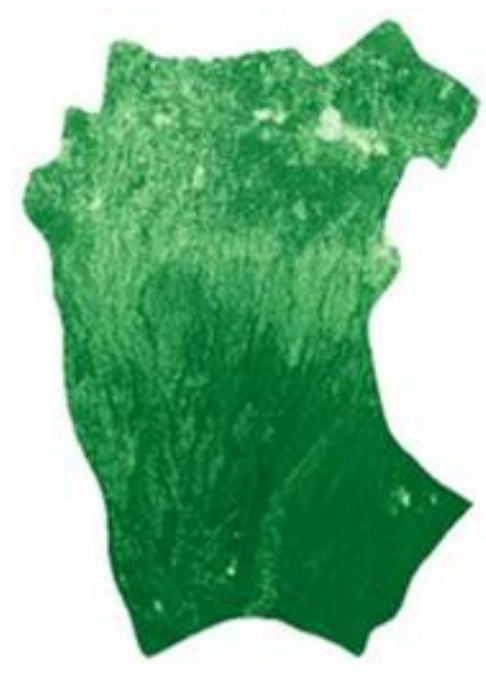

( a )

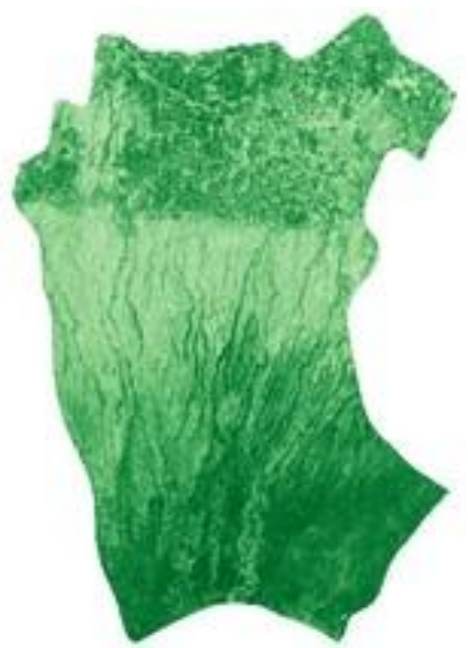

(d)

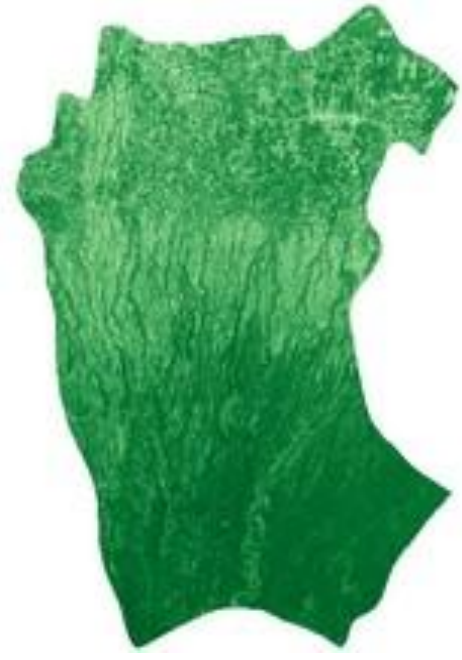

( b)

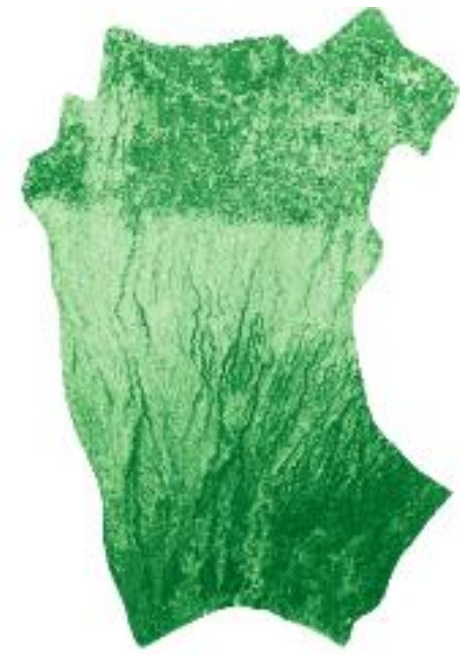

( e )

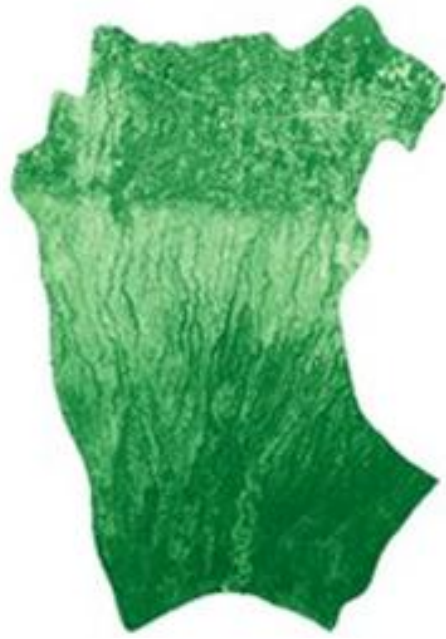

( c)

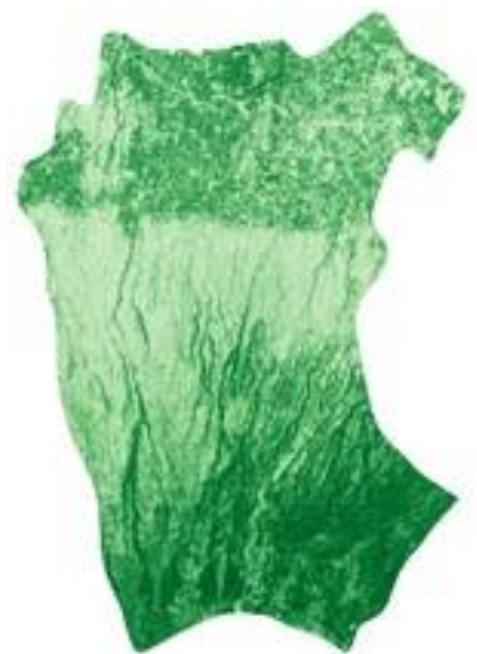

(f)

Gambar 3. NDVI bulan Mei-Oktober (a) Mei (b) Juni (c) Juli (d) Agustus (e) September (f) Oktober 


\subsection{Histogram}

Selanjutnya, gambar (4) menampilkan histogram NDVI dari citra bulan Mei sampai dengan Oktober. Pada histogram tersebut, terlihat bahwa histogram pada bulan Mei identik dengan histogram bulan Juni. Yang bulan Agustus mirip dengan pola histogram bulan september. Demikian juga untuk bulan September dan Oktober memiliki bentuk histogram yang serupa.

Gambar 4. menunjukkan distribusi spasial vegetasi dari bulan Mei sd Oktober. Diasumsikan bahwa dengan melihat bentuk histogram, maka dapat dianggap 4 bulan yang memiliki sebaran vegetasi yang konstan dan dianggap sebagai puncak musim kemarau yaitu pada bulan Juli, Agustus, September dan Oktober.

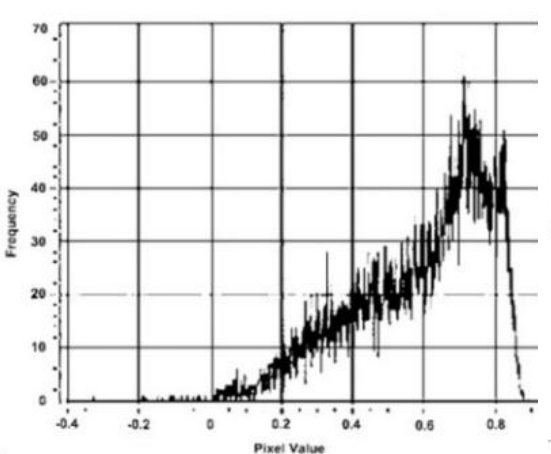

(a)

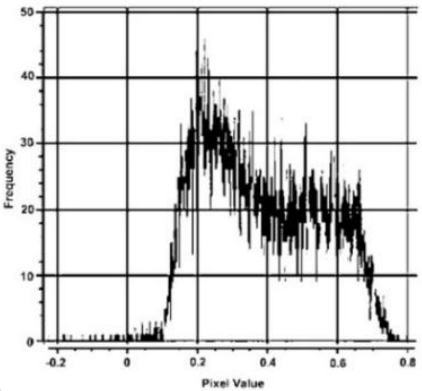

(d)

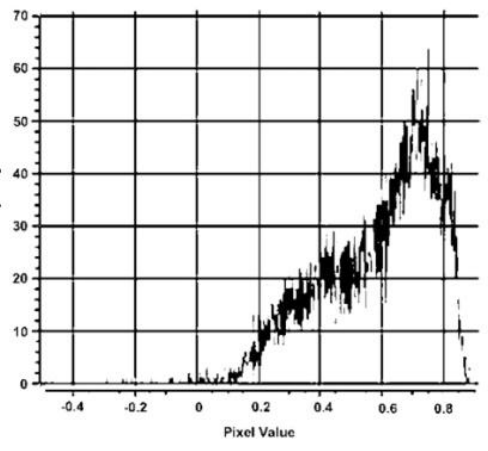

(b)

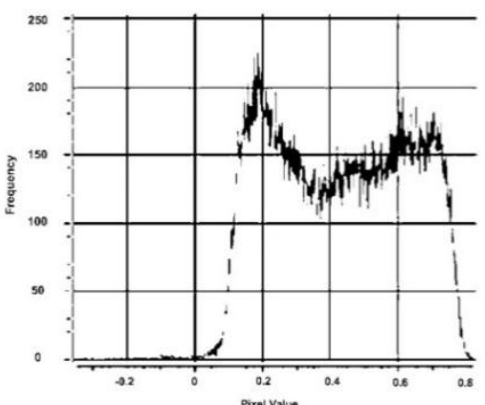

(e)

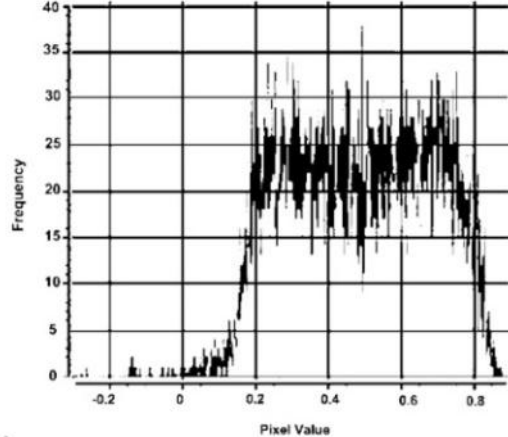

(c)

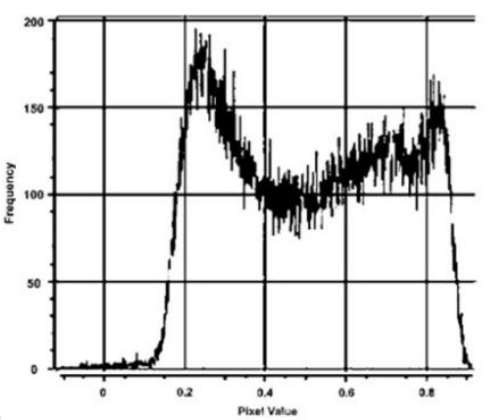

(f)

Gambar 4. Histogram NDVI bulan Mei-Oktober (a) Mei, (b) Juni, (c) Juli,(d) Agustus, (e) September, (f) Oktober

\subsection{Identifikasi Nilai NDVI}

Nilai NDVI yang telah diidentifikasi direkap pada Microsoft excel. Nilai NDVI yang telah diidentifikasi dari setiap kelas dapat dilihat pada Tabel $2 a$ sd $2 \mathrm{f}$.

Tabel 2a. Nilai NDVI pada fitur Sawah

\begin{tabular}{ccccc}
\hline \multirow{2}{*}{ No } & \multirow{4}{c}{ NDVI Sawah } \\
& Juli & Agustus & Sept & Oktober \\
\hline 1 & 0,656 & 0,657 & 0,567 & 0,656 \\
2 & 0,656 & 0,626 & 0,656 & 0,539 \\
3 & 0,682 & 0,574 & 0,496 & 0,486 \\
4 & 0,513 & 0,435 & 0,512 & 0,479 \\
5 & 0,465 & 0,479 & 0,479 & 0,454 \\
6 & 0,621 & 0,567 & 0,587 & 0,484 \\
7 & 0,656 & 0,656 & 0,484 & 0,385 \\
8 & 0,524 & 0,479 & 0,657 & 0,479 \\
\multicolumn{5}{c}{ Modus (0,479-0,656) } \\
\hline \multicolumn{5}{c}{}
\end{tabular}

Tabel 2b. Nilai NDVI pada pemukiman

\begin{tabular}{ccccc}
\hline No & \multicolumn{4}{c}{ NDVI Pemukiman } \\
& Juli & Agustus & Sept & Oktober \\
\hline 1 & 0,113 & 0,103 & 0,036 & 0,036 \\
2 & 0,127 & 0,136 & 0,098 & 0,098 \\
3 & 0,162 & 0,130 & 0,125 & 0,125 \\
4 & 0,135 & 0,045 & 0,114 & 0,120 \\
5 & 0,129 & 0,104 & 0,130 & 0,128 \\
6 & 0,135 & 0,135 & 0,126 & 0,135 \\
7 & 0,043 & 0,016 & 0,036 & 0,036 \\
8 & 0,126 & 0,135 & 0,044 & 0,135 \\
\multicolumn{5}{c}{ Modus (0,036-0,135) } \\
\hline \multicolumn{5}{c}{}
\end{tabular}


Tabel 2c. Nilai NDVI pada fitur Tegalan

\begin{tabular}{ccccc}
\hline \multirow{2}{*}{ No } & \multicolumn{4}{c}{ NDVI Tegalan } \\
& Juli & Agustus & Sept & Oktober \\
\hline 1 & 0,465 & 0,477 & 0,357 & 0,357 \\
2 & 0,598 & 0,468 & 0,479 & 0,359 \\
3 & 0,455 & 0,574 & 0,357 & 0,396 \\
4 & 0,478 & 0,435 & 0,317 & 0,358 \\
5 & 0,461 & 0,416 & 0,354 & 0,384 \\
6 & 0,472 & 0,458 & 0,474 & 0,354 \\
7 & 0,471 & 0,432 & 0,475 & 0,374 \\
8 & 0,478 & 0,478 & 0,394 & 0,358 \\
\multicolumn{5}{c}{ Modus ( o,136-0,357) } \\
\hline
\end{tabular}

Tabel 2e. Nilai NDVI Hutan-kebun

\begin{tabular}{ccccc}
\hline \multirow{2}{*}{ No } & \multicolumn{4}{c}{ NDVI Hutan - Perkebunan } \\
& Juli & Agustus & Sept & Oktober \\
\hline 1 & 0,827 & 0,816 & 0,751 & 0,753 \\
2 & 0,812 & 0,771 & 0,686 & 0,696 \\
3 & 0,855 & 0,854 & 0,731 & 0,761 \\
4 & 0,864 & 0,854 & 0,721 & 0,711 \\
5 & 0,777 & 0,790 & 0,657 & 0,765 \\
6 & 0,756 & 0,782 & 0,657 & 0,697 \\
7 & 0,697 & 0,790 & 0,678 & 0,693 \\
8 & 0,657 & 0,810 & 0,702 & 0,657 \\
\multicolumn{5}{c}{ Modus (o,657-1,0) } \\
\hline
\end{tabular}

Tabel 2d. Nilai NDVI pada LSO Kering

\begin{tabular}{ccccc}
\hline No & \multicolumn{4}{c}{ NDVI LSO Kering } \\
& Juli & Agustus & Sept & Oktober \\
\hline 1 & 0,136 & 0,141 & 0,110 & 0,130 \\
2 & 0,224 & 0,119 & 0,136 & 0,136 \\
3 & 0,356 & 0,235 & 0,138 & 0,138 \\
4 & 0,372 & 0,242 & 0,136 & 0,243 \\
5 & 0,258 & 0,159 & 0,128 & 0,128 \\
6 & 0,357 & 0,358 & 0,290 & 0,290 \\
7 & 0,259 & 0,362 & 0,321 & 0,321 \\
8 & 0,357 & 0,351 & 0,358 & 0,357 \\
\multicolumn{5}{c}{ Modus $(0,358-0,478)$} \\
\hline
\end{tabular}

Tabel 2f. Nilai NDVI Badan air

\begin{tabular}{ccccc}
\hline No & \multicolumn{4}{c}{ NDVI } \\
& Juli & Agustus & Sept & Oktober \\
\hline 1 & $-0,150$ & $-0,122$ & $-0,270$ & $-0,234$ \\
2 & 0,035 & 0,009 & $-0,204$ & $-0,214$ \\
3 & 0,035 & 0,046 & $-0,056$ & $-0,006$ \\
4 & 0,063 & $-0,105$ & $-0,208$ & $-0,205$ \\
5 & 0,034 & 0,035 & $-0,112$ & $-0,112$ \\
\multicolumn{5}{c}{ Modus $(-1-0,035)$} \\
\hline
\end{tabular}

Tabel 2. menunjukkan nilai NDVI pada setiap kelasnya, berdasarkan pada titik kontrol (GCP) yang ada. Nilai-nilai tersebut dianggap mewakili nilai dari setiap kelas yang diidentifikasi untuk proses selanjutnya. Data tersebut menunjukkan bahwa lahan non-vegetasi mempunyai nilai yang sangat kecil bahkan memiliki nilai negatif. Sebaliknya wilayah dengan vegetasi lebat (misalnya: hutan-kebun) memiliki nilai $N D V I$ yang tinggi. Nilai $N D V I$ pada fitur sawah dan tegalan, lahan kering dan pemukiman relatif saling berdekatan dan ada nilai yang tumpang tindih (overlap).

\subsection{Nilai Rentang NDVI}

Nilai rentang NDVI adalah dari -1 sampai dengan 1. Rentang nilai $N D V I$ digunakan sebagai dasar klasifikasi citra. Pada kelas pemukiman nilai modus terkecil $=0,036$ dan terbesar $=0,135$. Pada kelas "badan air" Nilai modus $N D V I=(-1$ sd 0 ,035) dan seterusnya nilai modus minimum dan maksimum dicantumkan di bawah tiap tabel. Selanjutnya, nilai modus minimum - maksimum digunakan sebagai dasar klasifikasi.

\subsection{Hasil Klasifikasi Citra NDVI}

Klasifikasi citra menghasilkan enam kelas yaitu; (1) badan air, (2) pemukiman, (3) lahan kering, (4) sawah irigasi, (5) tegalan dan (6) hutan-perkebunan. Gambar 5 menampilkan peta hasil klasifikasi ke enam (6) kelas tersebut berdasarkan nilai modus NDVI dari bulan Juli, agustus, sepetember dan oktober.

Ada beberapa erorr yang terjadi dalam interpretasi citra dengan metode NDVI. Error terjadi seperti interpretasi area pemukiman dengan area lahan kering. Lahan kering dan pemukiman pada citra 
memiliki Nilai NDVI relatif overlap, sehingga hasil klasifikasi menjadi kurang sesuai dengan kenyataan di lapang. Area pemukiman dianggap sebagai area lahan kering. Hal ini disebabkan karena karakteristik pemukiman dan lahan kering memiliki tingkat vegetasi yang rendah sehingga mempunyai value yang sama dan resiko terjadinya overlap sangat tinggi. Hal tersebut juga berlaku pada area sawah irigasi dengan area tegalan, dikarenakan value yang hampir sama sehingga tingkat terjadinya overlap menjadi tinggi.

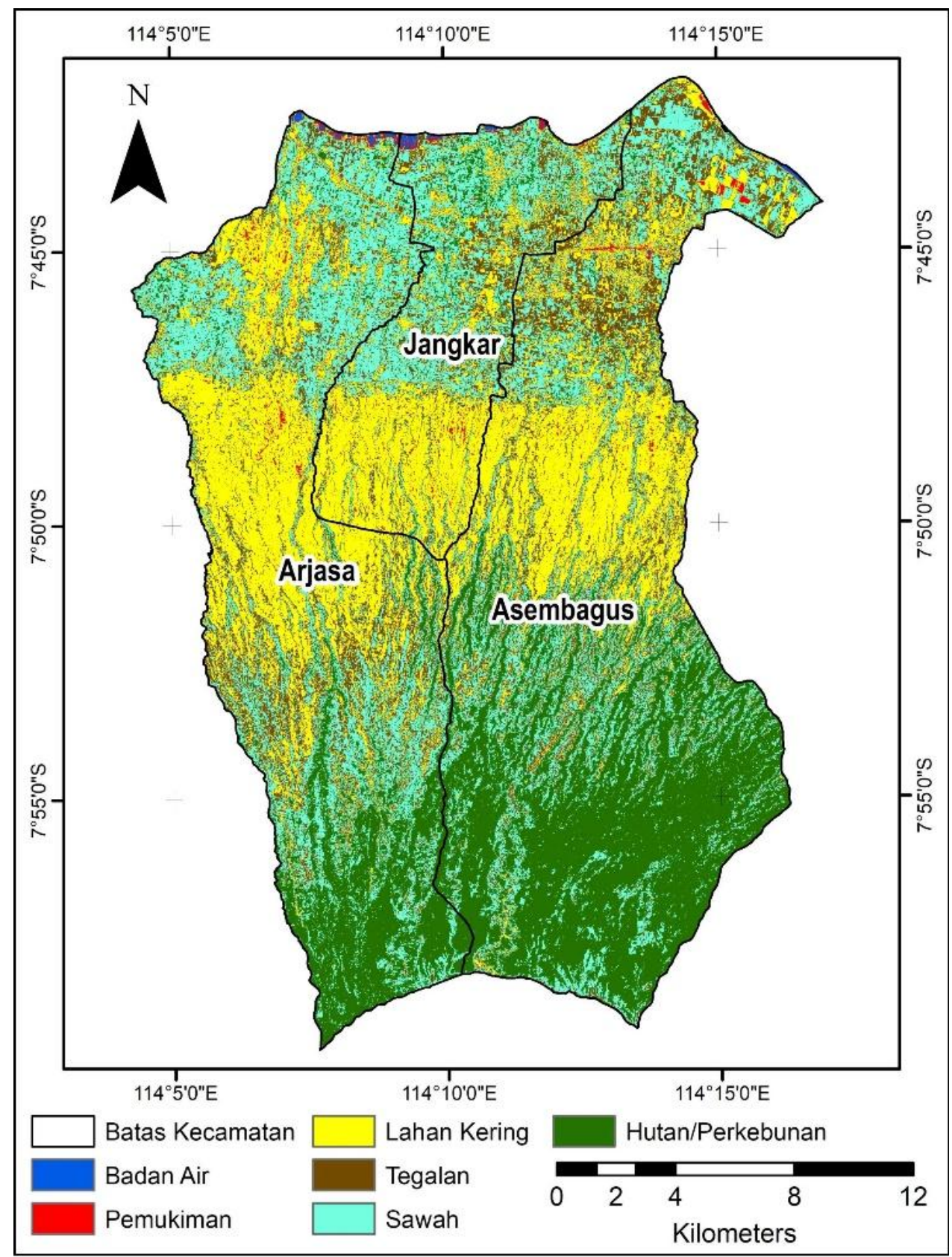

Gambar 5. Hasil Klasifikasi Metode NDVI.

\subsection{Uji Akurasi}

Menurut (LAPAN, 2015) klasifikasi yang baik harus memenuhi standar. Salah satunya adalah tingkat ketelitian klasifikasi yang dihasilkan harus $>=75 \%$. Berdasarkan Tabel 3 bahwa hasil akurasi secara keseluruhan 66,9\% dan akurasi kappa 61,6\%. Sedangkan syarat yang ditetapkan oleh USGS $(>85 \%)$, pada penelitian ini untuk uji akurasi masih belum memenuhi syarat yang ditetapkan USGS. Hal ini disebabkan klasifikasi metode NDVI mempunyai beberapa kelemahan diantaranya penentuan 
rentang NDVI dengan modus min dan modus max sehingga masih ada nilai max dan min yang menjadi penyebab error. Banyaknya nilai yang overlap membuat interpretasi menjadi sulit dilakukan sehingga menyebabkan akurasi menjadi kurang baik. Kerapatan vegetasi yang berubah-ubah tiap bulannya menjadi kendala tersendiri hal tersebut membuat value pada titik GCP menjadi tidak konstan pada ke empat bulan yang dianalisis.

Tabel 3. Hasil uji akurasi

\begin{tabular}{|c|c|c|c|c|c|c|c|c|}
\hline \multirow{2}{*}{$\begin{array}{c}\text { Data } \\
\text { Referensi }\end{array}$} & \multirow{2}{*}{$\begin{array}{c}\text { Akurasi } \\
\text { Referensi } \\
(\%)\end{array}$} & \multicolumn{6}{|c|}{ Kelas yang diklasifikasikan } & \multirow[t]{2}{*}{ Total } \\
\hline & & $\begin{array}{c}\text { Badan } \\
\text { Air }\end{array}$ & $\begin{array}{l}\text { Pemuki } \\
\text { man }\end{array}$ & $\begin{array}{l}\text { Lahan } \\
\text { Kering }\end{array}$ & Tegalan & $\begin{array}{l}\text { Sawah } \\
\text { Irigasi }\end{array}$ & $\begin{array}{c}\text { Hutan- } \\
\text { Perkebunan }\end{array}$ & \\
\hline Badan Air & 100.00 & 59 & o & $\mathrm{O}$ & $\mathrm{O}$ & o & o & 59 \\
\hline Pemukiman & 78.67 & 2 & 59 & 13 & 1 & $\mathrm{o}$ & o & 75 \\
\hline Lahan Kering & 82.86 & o & 11 & 58 & 1 & o & o & 70 \\
\hline Tegalan & 67.82 & $\mathrm{o}$ & 4 & 5 & 59 & 15 & 4 & 87 \\
\hline Sawah Irigasi & 82.50 & o & o & o & 12 & 66 & 2 & 80 \\
\hline $\begin{array}{l}\text { Hutan- } \\
\text { Perkebunan }\end{array}$ & 89.87 & o & o & o & o & 8 & 71 & 79 \\
\hline \multicolumn{2}{|c|}{ Total } & 61 & 74 & 76 & 73 & 89 & 77 & 450 \\
\hline \multicolumn{2}{|c|}{ Akurasi Aktual (\%) } & 96.72 & $79 \cdot 73$ & 76.32 & 80.82 & 74.16 & 92.21 & \\
\hline
\end{tabular}

Keterangan:

a. Badan Air; b. Pemukiman; c. Lahan Kering; d. Tegalan; e. Sawah Irigasi; f. Hutan-Perkebunan

Overall accuracy $=82,67 \%$, Kappa accuracy $=80 \%$

\subsection{Perhitungan Luas Lahan}

Tabel 4 menampilkan luas tiap kelas dan prosentase terhadap luas total wilayah studi. Hasil pemetaan menunjukkan prosentese luas yang cukup besar pada lahan kering, sawah irigasi, hutan dan tegalan.

Tabel 4. Luas dan \% luas hasil klasifikasi

\begin{tabular}{clcc}
\hline \multirow{2}{*}{ No } & \multirow{2}{*}{ Kelas } & \multicolumn{2}{c}{ Hasil } \\
\cline { 3 - 4 } & & \multicolumn{2}{c}{ klasifikasi } \\
\hline $\left.1 \mathrm{~km}^{2}\right)$ & $(\%)$ \\
\hline 2 & Pemukiman & 2,30 & 0,50 \\
3 & Lahan kering & 129,6 & 28,07 \\
4 & Hutan & 131,2 & 28,43 \\
5 & Tegalan & 84,03 & 18,20 \\
6 & Badan air & 0,62 & 0,14 \\
\hline & Total & 461,7 & 100 \\
\hline
\end{tabular}

Selanjutnya, tabel (5) menampilkan perbandingan hasil pemetaan pada area yang sama antara NDVI dan hasil pemetaan menggunakan metode klasifikasi supervised dengan algorithma maximum likelihood yang telah diteliti sebelumnya oleh Kholifah (Kholifah, 2019) dan peta Rupa Bumi Indonesia (RBI). Peta RBI diunduh dari BIG dan merupakan peta digital yang berasal dari peta non-digital keluaran tahun 2001 oleh Bakosurtanal.

Pembahasan hasil klasifikasi supervised dan peta RBI dapat dijumpai dalam tulisan Kholifah (2019). Secara umum dapat dikatakan bahwa peta RBI menggambarkan kondisi penutupan lahan tahun 20o1. Sementara metode klasifikasi supervised dan hasil klasifikasi NDVI mengacu pada kondisi 
penutupan lahan atau peruntukan lahan tahun 2018. Klasifikasi metode supervised menghasilkan nilai indeks overall dan kappa 95,8\% dan 93\% (tergolong sukses dan layak) (Kholifah, 2019).

Tabel 5. Hasil perbandingan luas lahan

\begin{tabular}{clcccccc}
\hline \multirow{2}{*}{ No } & \multirow{2}{*}{ Kelas } & \multicolumn{2}{c}{ Metode NDVI } & \multicolumn{2}{c}{$\begin{array}{c}\text { Supervised } \\
\text { Kholifah, 2019) }\end{array}$} & \multicolumn{2}{c}{ RBI } \\
\cline { 3 - 8 } & & $\left(\mathrm{km}^{2}\right)$ & $(\%)$ & $\left(\mathrm{km}^{2}\right)$ & $(\%)$ & $\left(\mathrm{km}^{2}\right)$ & $(\%)$ \\
\hline 1 & Pemukiman & 2,30 & 0,50 & 35,2 & 7,6 & 16 & 3,5 \\
2 & Lahan kering & 129,6 & 28,1 & 121 & 26,2 & 158,4 & 34,3 \\
3 & Sawah irigasi & 131,2 & 28,4 & 114,4 & 24,8 & 101,4 & 22 \\
4 & Hutan & 113,9 & 24,6 & 163,9 & 35,5 & 121,4 & 26,3 \\
5 & Tegalan & 84,03 & 18,2 & 23 & 4,98 & 63,9 & 13,8 \\
6 & Badan air & 0,62 & 0,14 & 4,12 & 0,89 & 0,6 & 0,1 \\
\hline & Total & 461,7 & 100 & 461,7 & 100 & 461,7 & 100 \\
\hline
\end{tabular}

(Sumber : Pengolahan data, Peta RBI (Badan Informasi Geospasial, 2017))

Pada kasus ini, jika dibandingkan dengan metode supervised maka klasifikasi berbasis NDVI yang dilakukan pada penelitian ini cenderung untuk menghitung luas pemukiman, hutan-perkebunan lebih kecil dari seharusnya. Sebaliknya, klasifikasi berbasis NDVI juga cenderung overestimate dalam menghitung luas per kelas untuk sawah irigasi, lahan kering (LSO-kering) dan tegalan. Ketiga fitur peruntukan lahan pada bulan July, Agustus, September dan Oktober dapat saja memantulkan respon spektral yang hampir mirip, sehingga terjadi overlap ketika diklasifikasikan hanya berbasis nilai NDVI.

\section{Kesimpulan}

Klasifikasi menggunakan metode NDVI telah berhasil membedakan 6 kelas yaitu badan air, pemukiman, lahan kering, tegalan, sawah irigasi dan hutan-perkebunan. Namun demikian, hasil uji akurasi masih belum memenuhi standar klasifikasi yang ada. Penggunaan nilai NDVI secara langsung untuk proses klasifikasi kurang disarankan. Perlu kajian yang lebih komprehensif tentang karakteristik dan bulan spefisik mana yang dapat digunakan untuk menggambarkan variasi peruntukan lahan di lapangan dengan lebih baik.

\section{Ucapan Terima Kasih}

Terima kasih disampaikan kepada semua pihak yang telah terlibat dalam penelitian ini. Penelitian ini merupakan bagian dari Hibah penelitian DRPM RISTEK DIKTI Grant ID no: 7/E/KPT/2019; 175/SP2H/LT/DRPM/2019 and 1817/UN25.3.1/LT/2019, dengan judul " Peningkatan Produktivitas Lahan Sub-optimal di Wilayah Kabupaten Situbondo Jawa Timur” dikoordinir oleh Indarto tahun 2019 - 2020.

\section{Daftar Pustaka}

Ahmed, M., Else, B., Eklundh, L., Ardö, J., \& Seaquist, J. 2017. Dynamic response of NDVI to soil moisture variations during different hydrological regimes in the Sahel region. International Journal of Remote Sensing, 38(19), 5408-5429.

Badan Informasi Geospasial. 2017. Geospasial untuk Negeri. Retrieved January 25, 2019, from Pusat Pengelolaan dan Penyebarluasan Informasi Geospasial Badan Informasi Geospasial (BIG) website: http://tanahair.indonesia.go.id/portal-web

Badan Pusat Statistik. 2016. Situbondo dalam angka. Situbondo: BPS-Statistics of Situbondo Regency.

Ballitanah. 2016. Laporan Kinerja Balai Penelitian Tanah 2016.

Bayramov, E., Buchroithner, M., \& Bayramov, R. 2016. Quantitative assessment of 2014-2015 land-cover changes in Azerbaijan using object-based classification of LANDSAT-8 timeseries. Modeling Earth 
Systems and Environment, 2(1). https://doi.org/10.1007/s40808-016-0o88-8

Blankenship, W. D., Condon, L. A., \& Pyke, D. A. 2019. Hydroseeding tackifiers and dryland moss restoration potential. Restoration Ecology.

Bontemps, S., Arias, M., Cara, C., Dedieu, G., Guzzonato, E., Hagolle, O., ... Defourny, P. 2015. Building a data set over 12 globally distributed sites to support the development of agriculture monitoring applications with Sentinel-2. Remote Sensing, 7(12), 16062-16090. https://doi.org/10.3390/rs71215815

Chen, T., De Jeu, R. A. M., Liu, Y. Y., Van der Werf, G. R., \& Dolman, A. J. 2014. Using satellite based soil moisture to quantify the water driven variability in NDVI: A case study over mainland Australia. Remote Sensing of Environment, 140, 330-338.

Clerici, N., Valbuena Calderón, C. A., \& Posada, J. M. 2017. Fusion of sentinel-1a and sentinel-2A data for land cover mapping: A case study in the lower Magdalena region, Colombia. Journal of Maps, 13(2), 718-726. https://doi.org/10.108o/17445647.2017.1372316

Danoedoro, P. (2012). Pengantar penginderaan jauh digital. Yogyakarta: Andi.

Ghazanfari, S., Pande, S., Hashemy, M., \& Sonneveld, B. 2013. Diagnosis of GLDAS LSM based aridity index and dryland identification. Journal of Environmental Management, 119, 162-172.

Gherardi, L. A., \& Sala, O. E. 2019. Effect of interannual precipitation variability on dryland productivity: A global synthesis. Global Change Biology, 25(1), 269-276.

Glenn, N. F., Neuenschwander, A., Vierling, L. A., Spaete, L., Li, A., Shinneman, D. J., ... Mcllroy, S. K. 2016. Landsat 8 and ICESat-2: Performance and potential synergies for quantifying dryland ecosystem vegetation cover and biomass. Remote Sensing of Environment, 185, 233-242.

Gu, Y., Hunt, E., Wardlow, B., Basara, J. B., Brown, J. F., \& Verdin, J. P. 2008. Evaluation of MODIS NDVI and NDWI for vegetation drought monitoring using Oklahoma Mesonet soil moisture data. Geophysical Research Letters, 35(22).

Jaya, I. N. S., \& Surati, N. 2010. Analisis citra digital: perspektif penginderaan jauh untuk pengelolaan sumberdaya alam. Fakultas Kehutanan. Bogor (ID): Institut Pertanian Bogor.

Kawamuna, A., Suprayogi, A., \& Wijaya, A. P. 2017. Analisis kesehatan hutan mangrove berdasarkan metode klasifikasi NDVI pada citra Sentinel-2(Studi Kasus: Teluk Pangpang Kabupaten Banyuwangi). Geodesi Undip, 6, 277-284.

Kholifah, S. 2019. Klasifikasi dan Interpretasi citra satelit sentinel untuk pemetaan tutupan lahan pada wilayah (Arjasa, Asembagus dan Jangkar) Kabupaten Situbondo (Metode Unsupervised dan Supervised Classification). Universitas Jember.

LAPAN. 2015. Pedoman pengolahan data satelit multispektral secara digital supervised untuk klasifikasi. Jakarta: Pusat Pemanfaatan Penginderaan Jauh Lembaga Penerbangan dan Antariksa Nasional.

Las, I., M. S. A., \& Mulyani. 2012. Kunjungan kerja tematik dan penyusunan model/program percepatan pembangunan pertanian berbasis inovasi wilayah pengembangan khusus lahan suboptimal. Balai Besar Litbang Sumberdaya Lahan Pertanian, Bogor.

Naser, M. A., Khosla, R., Longchamps, L., \& Dahal, S. 2020. Using NDVI to Differentiate Wheat Genotypes Productivity Under Dryland and Irrigated Conditions. Remote Sensing, 12(5), 824.

Osgouei, P. E., Kaya, S., Sertel, E., \& Alganci, U. 2019. Separating built-up areas from bare land in mediterranean cities using Sentinel-2A imagery. Remote Sensing, 11(3). https://doi.org/10.339o/rs11030345

Putra, B. T. W., Soni, P., Marhaenanto, B., Harsono, S. S., \& Fountas, S. 2019. Using information from images for plantation monitoring: A review of solutions for smallholders. Information Processing in Agriculture.

Rahaman, K. R., Hassan, Q. K., \& Ahmed, M. R. 2017. Pan-Sharpening of Landsat-8 Images and its application in calculating vegetation greenness and canopy water contents. ISPRS International Journal of Geo-Information, 6(6), 168. https://doi.org/10.339o/ijgi6o6o168

Sinaga, S. H., Suprayogi, A., \& Haniah. 2018. Analisis ketersediaan ruang terbuka hijau dengan metode 
normalized difference vegetation index dan soil adjusted vegetation index menggunakan citra satelit sentinel-2a (Studi Kasus: Kabupaten Demak) Sulaiman. Geodesi Undip.

USGS. 2019. EarthExplorer - Home. U.S. Geological Survey. Retrieved from https://earthexplorer.usgs.gov/

Zewdie, W., Csaplovics, E., \& Inostroza, L. 2017. Monitoring ecosystem dynamics in northwestern Ethiopia using NDVI and climate variables to assess long term trends in dryland vegetation variability. Applied Geography, 79, 167-178. 